\title{
A SIMPLE HYDROPONIC SYSTEM FOR PEPPER PRODUCTION IN UPPER EGYPT
}

\author{
A. A. El-Nakib ${ }^{1}$ H. A. Abdel-Mawla ${ }^{2}$, A. M. El-Lithy ${ }^{3}$, \\ S. Hegab ${ }^{4}$ and Y. A. Abdel-Fattah ${ }^{5}$
}

\section{$\underline{\text { ABSTRACT }}$}

The aim of this research is to design and test an appropriate hydroponic system for pepper production in Upper Egypt to overcome the problems associated with expensive models that used high technology. The designed system has the following advantages: simple, available to all people in the upper Egypt to set up, fabricated from commercial available materials in the local market and easy to operate and maintain. The system was installed and tested on the roof (area $10 \mathrm{~m}^{2}: 5 \mathrm{~m}$ length $x$ $2 \mathrm{~m}$ height, covered with $20 \mathrm{~m}^{2}$ theran sheet to reduce hazard of sun radiation and high temperature on healthy plant growth and production ) building of Agricultural Engineering Department, Al Azhar University, Assiut branch through two seasons 2008-2009 and 2009-2010, for high quantity and quality pepper crop production with two irrigation cycles number 5 and 10 (cycle time of 15 min.), Flow rates (1.5, 2 and 2.5 L/min), and EC (electrical conductivity 2 and $3 \mathrm{mmhos} / \mathrm{cm}$ ) with $\mathrm{pH}$ range of 5.5 - 6.0. The main results showed that the optimum conditions for pepper crop "Bigmami" production by using the designed HYDROPONIC system were: flow rate of $2 \mathrm{~L} / \mathrm{min}$, electrical conductivity "EC" of 3 mmhos/cm and irrigation cycle number of 10 /day. The results obtained in optimum conditions were: Average root length per plant $=18.6 \mathrm{~cm}$, Average total leaves area $=8290.4 \mathrm{~cm}^{2}$, average total fruits yield $=6.0 \mathrm{~kg} /$ plant, Maximum consumptive water use $=18 \mathrm{~L} /$ plant $/$ season, Average water use efficiency $=333 \mathrm{~g} / \mathrm{L}$, and the cost of produce $1 \mathrm{~kg}$ of pepper fruits was $1.27 \mathrm{L.E.}$.

(1) Prof. of Ag. Eng. Dept., Fac. of Ag., AL - Azhar Univ, Cairo,

(2) Prof. and Head of Ag. Dept. Fac. of Ag., AL-Azhar Univ, Assiut.

(3) Associated Prof. of Ag. Eng. Dept., Fac. of Ag., AL-Azhar Univ, Assiut.

(4) Prof. and Head of Soils and Water Dept, Fac. of Ag., AL-Azhar Univ, Assiut.

(5) M. Sc. Student, Ag. Eng. Dept., Fac. of Ag., AL-Azhar Univ, Assiut. 


\section{INTRDODUCTION}

epper is one of the important crops grown under protected
cultivation in Egypt. It presents about $25 \%$ of the cultivation
under plastic houses, Anonimous (2003).

Abou-Hadid et al., (1995) tested different growing media for producing cucumber under Egyptian condition. The tested growing media were peat moss: sand : vermiculite $(1: 1: 1 \mathrm{v} / \mathrm{v} / \mathrm{v})$, peat moss :vermiculite $(1 / 1 \mathrm{v} / \mathrm{v})$, peat moss : sand $(1: 1 \mathrm{v} / \mathrm{v})$ and rock wool in comparison with the traditional cultivation in soil. They found that the peat -based mixture gave higher number of leaves than the other growing media .

El- Behariy et al., (2001 a) indicated that plants grown in NFT system gave higher total leaf area than substrate system (sponge).

The advantages of simplified HYDROPONIC (SH) were summarized in the following points, Caldeyro (2003):

- It is a low cost and easy-to-learn technique.

- It allows the production of vegetables "without soil" in containers with water or in low-cost natural substrates (sand, rice skulls, pumice stone, etc.). It allows to grow a wide variety of vegetables, such as lettuce, tomatoes, carrots, garlic, watercress, aborigines, beans, parsley, radish, leek, strawberries, melons, flowers, aromatic and medicinal plants, etc.

- It allows the use of recycled materials to build the containers, thus making low-cost materials such as wood and disposable containers, useful.

- It is ideal for food production in Urban Agriculture. It offers the advantage of using places that have not previously been thought appropriate for food production (courtyards, small gardens, walls, balconies, rooftops).

- High efficiency of the use of water, but requires uncontaminated water availability.

- Generation of direct income for family or community micro enterprises. 
- It allows the production of high quality, harmless food. The fruits and vegetables have a very high biological and nutritional value. Since they are grown by the family, they are harvested immediately before their use, thus, the products are fresh and they keep their nutritional and medicinal qualities intact. Another advantage for the settlements is that it allows cultivation out of the ground, harmless and uncontaminated. In order to assure the harmlessness of the final product, it is essential to use drinking water and / or clean rainwater.

Hydroponic systems are classified in either open or closed. In the open system, which is an intermittent system, the nutrient solution either flows through cultivation tubes or is deposited onto the cultivation substrates, and the exceeding amounts return to the catchment tank. In the closed system, which is a static-intermittent system, the nutrient solution is injected only once per irrigation cycle and the remaining solution is not returned to the catchment tank (Resh 1997 and Jensen 1999).

Haddad and Boukhris (2003) demonstrated that both very early and early marketable yields of tomato were not affected by substrate type but total yield was higher in sand grown plants compared perlite grown plants.

HYDROPONIC is a technology for growing plants in nutrient solution (water containing fertilizer) with or without use of an artificial medium (sand, gravel, vermiculite, rock wool, polite, peat moss, coir, or sawdust) to provide mechanical support. Liquid HYDROPONIC systems have no other supporting medium for the plant roots

HYDROPONIC is the production of plants in a soilless medium whereby all of the nutrients supplied to the crop are dissolved in water. Liquid hydroponic systems employ the nutrient film technique (NFT), floating rafts, and no circulating water culture. Aggregate hydroponic systems employ inert, organic, and mixed media contained in bag, trough, trench, pipe, or bench setups.

Aggregate media used in these systems include perlite, vermiculite, gravel, sand, expanded clay, peat, and sawdust. Normally, hydroponic plants are fertile (soluble fertilizers injected into irrigation water) on a 
periodical cycle to maintain moist roots and provide a constant supply of nutrients. These hydroponic nutrients are usually derived from synthetic commercial fertilizers, such as calcium nitrate, that are highly soluble in water. Hydroponic recipes are based on chemical formulations that deliver precise concentrations of mineral elements. The controlled delivery of nutrients, water, and environmental modifications under greenhouse conditions is a major reason why HYDROPONIC is so successful.

Jensen and Collins (1985) published a complete review of HYDROPONIC highlighting many new cultural systems developed in Europe and the United States.

Merle Jensen (1997) mentioned that the European glass structures that today are commonly being built for vegetable production in the southwestern part of the United States are very different from the polyethylene/fiberglass houses used in HYDROPONIC production between 1965 and 1990

EL- Beltage et al. (1992) reported that cucumber plant grown in peat moss + sand + vermiculite $(1: 1: 1)$ substrate yielded higher vigorous plant than those grown in other in tested mixed media.

Ahmed (2003) indicated that the highest total leaf area was obtained by using sand: peat moss: perlite " $3: 1: 1 \mathrm{v} / \mathrm{v} / \mathrm{v}$ " substrate then Ashape NFT system, while the lowest value was obtained by the aeroponic system.

Bohme (1994) demonstrated that highest total yields were recorded from the plants grown in compound organic substrates, compared with rock wool mats, perlite and urea foam.

Marle and Jensen (1997) concluded that the general recommendations outlined in "Application of fertilizer and water." Target $5 \%$ over drain early in the cycle and increase over drain up $30 \%$ in summer. Increase the amount of water in accordance with the demands of the plant.

Tuzel et al. (2001) reported that there were an interaction between substrate volume and substrate type and irrigation times, where the highest yield of tomato plant was recorded for plants irrigated four times a day and substrate volume 8 liter per plant. 


\section{MATERIALS AND METHODS}

\section{- Materials:}

- The designed HYDROPONIC system:

The designed HYDROPONIC system consists of the following parts as shown in fig. 1a and $b$ :

\section{(a) Nutrient solution tank.}

A nutrient solution plastic-tank has $80 \mathrm{~cm}$ diameter and $90 \mathrm{~cm}$ height (volume of 450 liter).

\section{(b) Nutrient solution.}

The composition of the nutrients solution (Hogland) that used in experiment were maintained ranged from 2 to $3 \mathrm{~m} . \mathrm{mhos} / \mathrm{cm}$ for EC and $\mathrm{pH}$ of 5.8 to 6.0 by using digital $\mathrm{EC}$ and $\mathrm{pH}$ meter during the experiments.

\section{(c) Pump and Timer.}

Centrifugal pump of $0.38 \mathrm{kw}$ was used in this experiment to circulate the nutrient solution between nutrient solution tank and pipes. In addition to timer was used to control irrigation cycle time with increment of $15 \mathrm{~min}$.

The pumping of the nutrient solution from the tank was performed automatically during nursery and growing stages, starting on irrigation cycles times for ( at 7:00 a.m., maintaining an intermittent nutrient flow, working for $15 \mathrm{~min}$, during the production phase, until 12.00 p.m.. At night).

\section{(c) P.V.C pipe.}

Three 4" PVC pipes (4 m length) with 12 hole (diameter of $75 \mathrm{~mm}$ ) fixed horizontally on the roof wall in zero level with $50 \mathrm{~cm}$ spacing were used to support the plants in pipe hole using polyethylene bag, with diameter of $75 \mathrm{~mm}$. and in order to control and maintain the flow rate in pipes within desired limit ( solution height $52.5 \mathrm{~mm}$ of inside pipe diameter), two 1" valves used on each pipe inlet and outlet.

-Tested crop.Pepper crop "Bigmami" variety was cultivated in this study. 


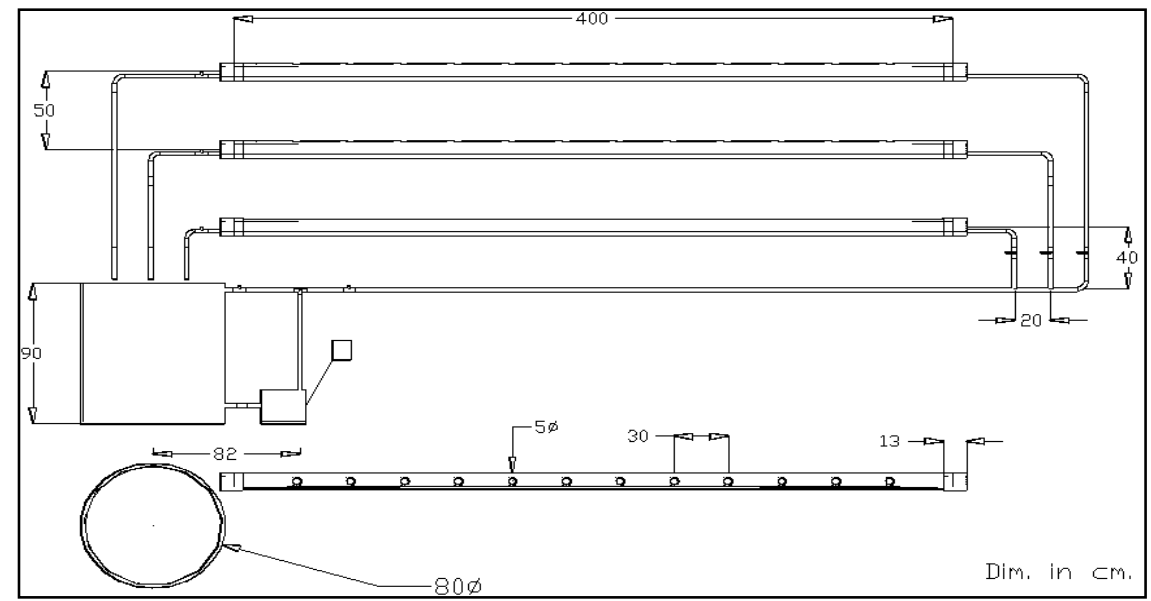

(A)

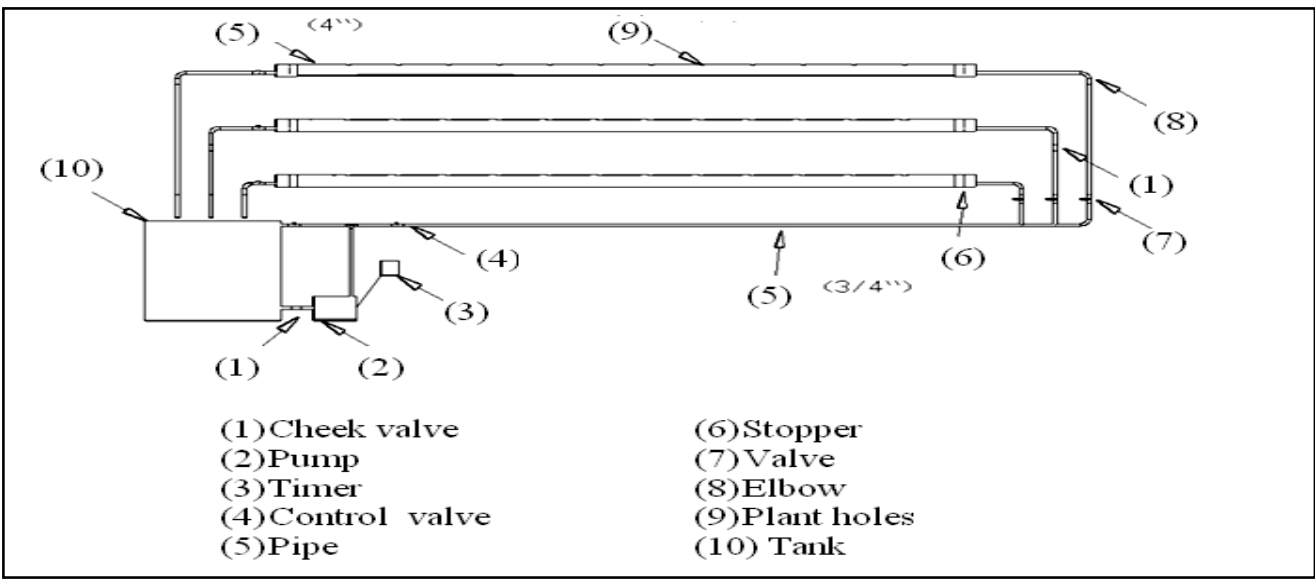

(B)

Figure 1:(A) The developed hydroponic system with dimensions.

(B) The Schematic diagram of developed hydroponic system

\section{-Instrumentations:}

- $\mathrm{pH}$ meter range 0-14 with accuracy of 0.1.

- EC meter range 1-3 mmhos/cm and accuracy of $0.001 \mathrm{mmhos} / \mathrm{cm}$.

- Thermometer glasses with range of $0-200 \mathrm{C}^{\circ}$ was used.

- Total surface leaves area was determined using L1-300 portable area-meter.

- Relative humidity was determined using RH meter (RH 200). 


\section{-Methods:}

\section{- Studied factors:}

1- Irrigation cycle: Timer adjusted to give 5,10 irrigation circulation time (15 min) with Start times at 7,9,11 am and 1,4 pm in the first season (2008-2009) and in the second season (2009-2010) start times were 3,7,9,11 am. and 1,3,5,7,10.12 pm.

2- Flow rate: Included of three discharge $(1.5,2$ and $2.5 \mathrm{~L} / \mathrm{min})$ were adjusted using control valves, graduated cylinder and stop watch.

3- Electrical Conductivity ( EC) : were adjusted at 2 and $3 \mathrm{mmhos} / \mathrm{cm}$ using Hogland solution and EC meter.

\section{Measurements:}

-Microclimate factor: light intensity (foot-candles), average temperature $\left(\mathrm{C}^{\circ}\right)$ and Relative humidity $(\%)$.

-Solution measurements: electrical conductivity (EC) and humidity (pH ).

-Plant growth parameters: Root length, total leaves area, and total yield, consumptive water use using Blaney-Criddle equation (Ponce 1989).:

$$
\text { ETo }=p \cdot(0.46 \cdot \operatorname{Tmean}+8)
$$

Where:.

ETo: is the reference evapotranspiration [mm day-1] (monthly)

Tmean: is the mean daily temperature $\left[{ }^{\circ} \mathrm{C}\right]$

$\mathbf{p}$ :is the mean daily percentage of annual daytime hours.[1]

- Water use efficiency and Consumptive water use. -cost detail.

\section{RESULT AND DISCUSSION}

\section{-Effect of the flow rate on plant characteristics:}

\section{1- Root length.}

Fig. 1 shows that the maximum average root length of $18.6 \mathrm{~cm}$ on $10^{\text {th }}$ irrigation cycles number by using a solution with EC $3 \mathrm{mmhos} / \mathrm{cm}$ with flow rate $2 \mathrm{~L} / \mathrm{min}$ through season (2009-2010) . And, the minimum average root length $8.7 \mathrm{~cm}$ on $5^{\text {th }}$ irrigation cycles number by using a 
solution with EC $2 \mathrm{mmhos} / \mathrm{cm}$ with flow rate $1.5 \mathrm{~L} / \mathrm{min}$ through season (2008-2009) .

The increasing average root length with increasing of flow rate agrees with (Fahem 1989) results.

\section{2- Total leaves-area.}

Fig. 1 shows that the maximum average total leaves-area 7345.5 $\mathrm{cm}^{2}$ and $8290.4 \mathrm{~cm}^{2}$ on $10^{\text {th }}$ irrigation cycles number by using a solution were EC 2 and $3 \mathrm{mmhos} / \mathrm{cm}$ were flow rate $2 \mathrm{~L} / \mathrm{min}$ respectively at two seasons (2008-2009 and 2009-2010) respectively. Meanwhile, the minimum average total leaves-areas of $4605.6 \mathrm{~cm}^{2}$ and $5624.8 \mathrm{~cm}^{2}$ on $5^{\text {th }}$ irrigation cycles number by using a solution were EC 2 and $3 \mathrm{mmhos} / \mathrm{cm}$ for flow rate $1.5 \mathrm{~L} / \mathrm{min}$ at two seasons(2008-2009 and 2009-2010) respectively. The increasing total leaves-area may be due to increased of temperatures and Light intensity (foot-candles) recorded through season that agree with (Fahem 1989) results.
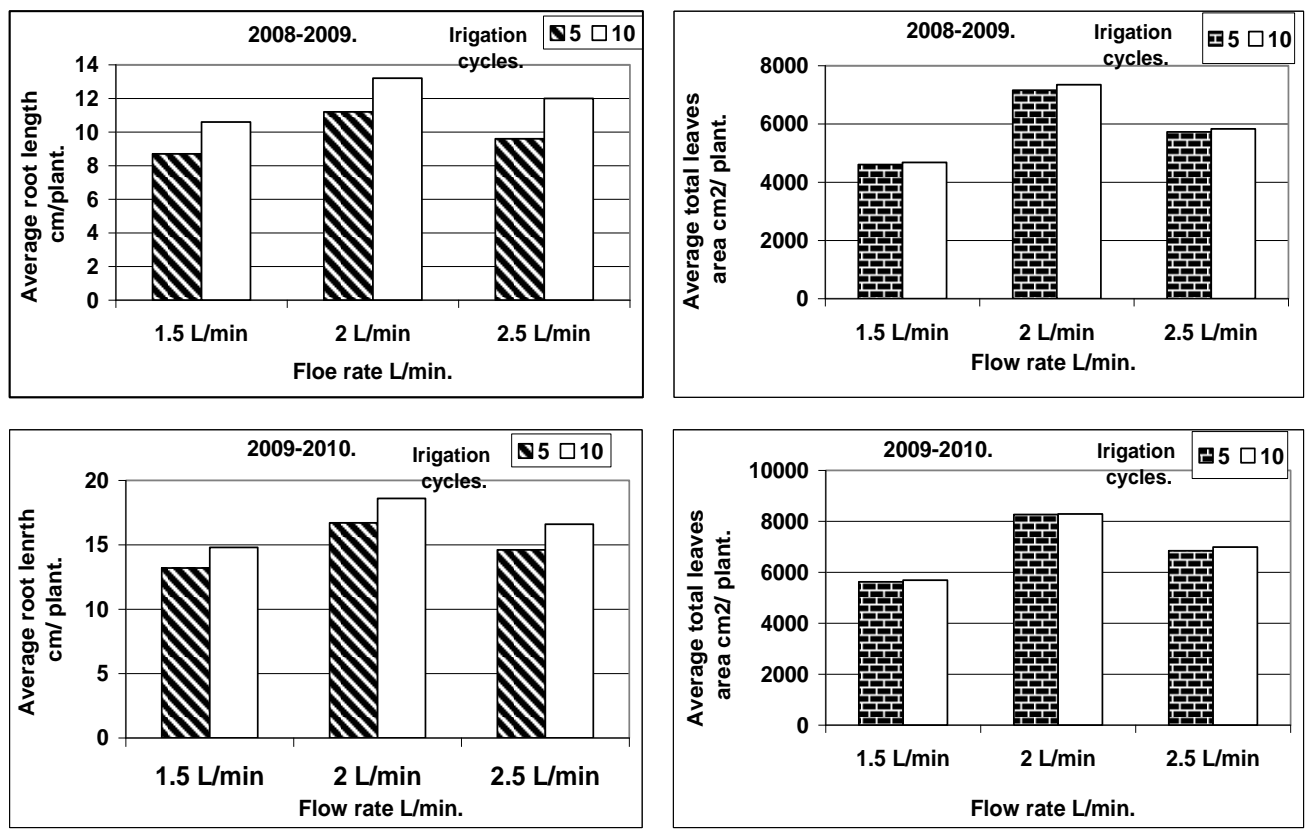

Fig.1: Effect of flow rate on average root length and total leaves area by using two irrigation-cycles number ( 5 and 10 / day) at two seasons. 


\section{- Effect of flow rate on total fruits-yield.}

Fig. 2 shows that the maximum average total fruits - yield of $6 \mathrm{~kg} /$ plant /season on $10^{\text {th }}$ irrigation cycles number by using a solution with EC $3 \mathrm{mmhos} / \mathrm{cm}$ for flow rate $2 \mathrm{~L} / \mathrm{min}$ through season (2009-2010).

Meanwhile, the minimum average total fruits yield $3 \mathrm{~kg} /$ plant /season on $5^{\text {th }}$ irrigation cycles number by using a solution with EC $2 \mathrm{mmhos} / \mathrm{cm}$ for flow rate $1.5 \mathrm{~L} / \mathrm{min}$ through season (2008-2009).

The increasing total fruits - yield may be due to increasing of flow rate and irrigation cycles number.
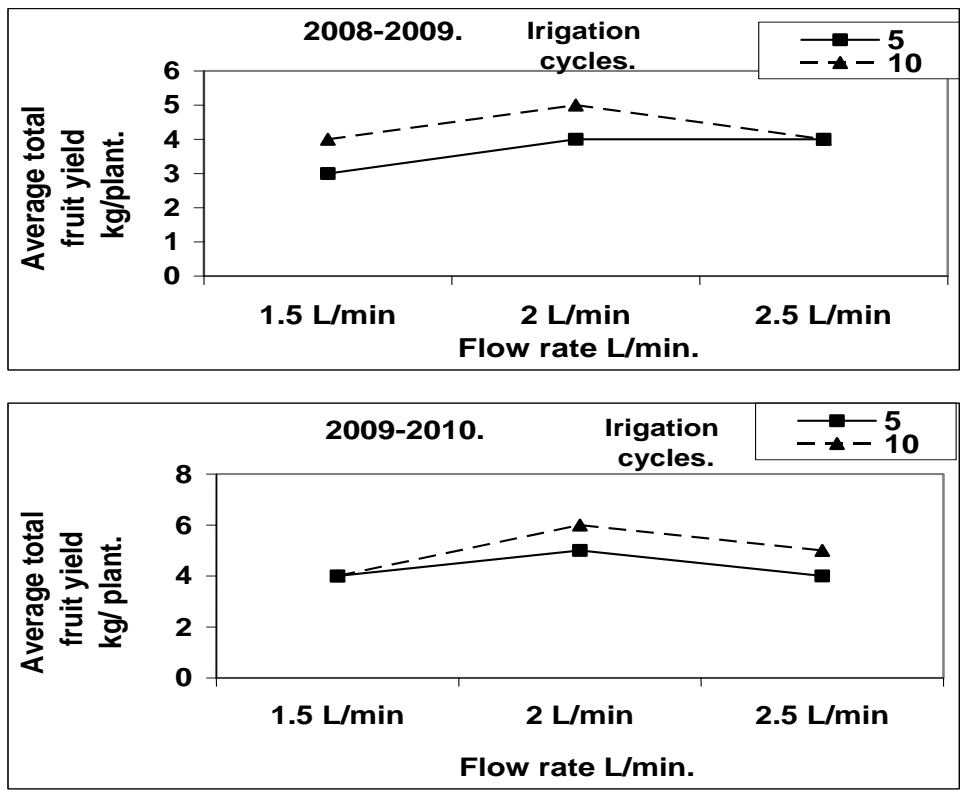

Fig. 2: Effect of flow rate on average total fruit yield by using two irrigation-cycles number ( 5 and 10 / day) at two seasons.

\section{-Consumptive water use.}

Average consumptive water use measured increased from 15 to $18 \mathrm{~L} /$ Plant/season through two seasons ( 2008-2009 and 2009-2010) respectively., Meanwhile calculated average consumptive water use using Blaney-Criddle equation (Ponce 1989) was 45 and 47 L/ Plant/season through two seasons ( 2008-2009 and 2009-2010) respectively. 


\section{-Effect of flow rate on water use efficiency.}

Fig. 3 shows that maximum water use efficiency of $333 \mathrm{~g} / \mathrm{L}$ was obtained with flow rate of $2 \mathrm{~L} / \mathrm{min}$, irrigation cycle number of 10/ day and "EC" of $3 \mathrm{mmhos} / \mathrm{cm}$ through seasons (2009-2010). Meanwhile, the minimum water use Efficiency of $200 \mathrm{~g} / \mathrm{L}$ was obtained with flow rate of 2.5 $\mathrm{L} / \mathrm{min}$, irrigation cycle number of 5/ day and "EC" of $2 \mathrm{mmhos} / \mathrm{cm}$ through seasons ( 2008-2009).
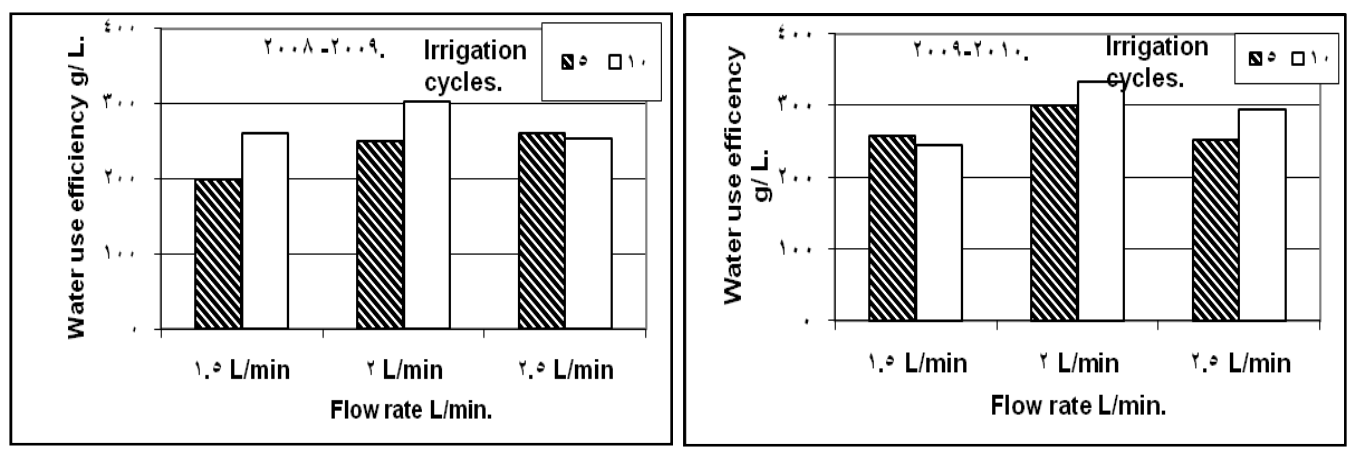

Fig. 3: Effect of flow rate on water use efficiency by using two irrigation-cycles number (5 and 10 / day) at different seasons.

-Effect of system cover (theran) on weather data :

Table 1 shows that using system cover encourage healthy plants growth and reduce hazard of high temperature on pepper plant by reducing average temperature, light intensity and relative humidity from $\left(32 \mathrm{C}^{\circ}\right.$, 190.3 foot- candle , $75.3 \%)$ to $\left(28.9 \mathrm{C}^{\circ}, 186\right.$ foot- candle , $\left.72.5 \%\right)$ through season $2008-2009$ and from $\left(33.2 \mathrm{C}^{\circ}, 195.6\right.$ foot- candle , 77.8\% ) to ( $30.8 \mathrm{C}^{\circ}$, 191 foot- candle , 75.1\%) through season $2009-2010$ respectively.

Table 1: Average measured weather data inside and outside system cover and through two seasons (2008-2009 and 2009/2010).

\begin{tabular}{|c|c|c|c|c|c|c|}
\hline \multirow{3}{*}{ Season } & \multicolumn{6}{|c|}{ Average of Weather data } \\
\cline { 2 - 7 } & \multicolumn{3}{|c|}{ Outside system cover } & \multicolumn{3}{c|}{ Inside system cover } \\
\cline { 2 - 7 } & $\begin{array}{c}\text { T } \\
\text { avg. } \\
\left(C^{\circ}\right)\end{array}$ & Li & $\begin{array}{c}\text { RH } \\
(\%) \text { avg. }\end{array}$ & $\begin{array}{c}\text { T } \\
\text { avg. } \\
\left(C^{\circ}\right)\end{array}$ & Li & $\begin{array}{c}\text { RH } \\
(\%)\end{array}$ \\
& & & avg. \\
\hline$(2008 / 2009)$ & 32.0 & 190.3 & 75.3 & 28.9 & 186 & 72.5 \\
\hline$(2009 / 2010)$ & 33.2 & 195.6 & 77.8 & 30.8 & 191 & 75.1 \\
\hline
\end{tabular}




\section{-Cost analysis:}

Table.2 Shows that total pepper plant productivity were 270 and 324 $\mathrm{kg} / \mathrm{season}$ for seasons ( 2008-2009 and 2009-2010) respectively. And also the average productivity per season was about $30 \mathrm{~kg} / \mathrm{m}^{2}$. Meanwhile the production cost of produce $1 \mathrm{~kg}$ pepper crop was about 1.27 L.E under the experimental conditions through two seasons ( 20082009 and 2009-2010) .

Table 2: The designed hydroponic system cost details.

\begin{tabular}{|c|c|c|c|}
\hline \multicolumn{4}{|c|}{ ACTUAI COST AND PRODUCTIVITY DATA } \\
\hline \multirow{2}{*}{ Cost items } & \multicolumn{2}{|c|}{ Actual season cost, L.E. } & \multirow{13}{*}{ Total } \\
\hline & \begin{tabular}{|l|}
$(2008-2009)$ \\
\end{tabular} & (2009-2010). & \\
\hline Seedlings & 30 & 30 & \\
\hline Nutrient solution tank & 15 & 15 & \\
\hline Nutrient solution & 50 & 50 & \\
\hline Pump & 50 & 50 & \\
\hline Timer & 30 & 30 & \\
\hline P.V.C pipes & 35 & 35 & \\
\hline fitting & 30 & 30 & \\
\hline Valves & 8 & 8 & \\
\hline Theran sheet & 40 & 40 & \\
\hline Electricity & 40 & 40 & \\
\hline Maintenance & 50 & 50 & \\
\hline Total cost ; L.E. & 378 & 378 & 756 \\
\hline $\begin{array}{c}\text { *Actual plant productivity } \\
\text { kg/season ( } 8 \text { month). }\end{array}$ & 5 & 6 & 11 \\
\hline ** Total Productivity, kg/season. & 270 & 324 & 594 \\
\hline$* * *$ Productivity $\mathrm{kg} / \mathrm{m} 2$ & 27 & 32.4 & 59.4 \\
\hline \multicolumn{3}{|c|}{$* * * *$ Production cost of one $\mathrm{kg} \mathrm{L.E.} / \mathrm{m}^{2}$} & 1.27 \\
\hline
\end{tabular}

*Actual plant productivity; kg/season. From the experment resultd Fig .2). ** Total productivity, $\mathrm{kg} /$ season $=($ Plant Productivity $/$ season $) *$ Number of pepper plants *** Productivity, $\mathrm{kg} / \mathrm{m} 2=$ Total productivity $/ * \operatorname{System}$ area $\left(10 \mathrm{~m}^{2}\right)$. **** Production cost of one $\mathrm{kg}, \mathrm{L.E} . / \mathrm{m} 2=$ Total cost $/$ Total productivity $*$ System area $\left(10 \mathrm{~m}^{2}\right)$.

\section{CONCLUSION}

The optimum conditions for Pepper crop "Bigmami" production by using the designed HYDROPONIC system were: flow rate of $2 \mathrm{~L} / \mathrm{min}$, nutrient solution electrical conductivity "EC" of $3 \mathrm{mmhos} / \mathrm{cm}$ and irrigation cycle 
number of 10 /day. The results obtained in optimum conditions were: Average season root length per plant $=18.6 \mathrm{~cm}$, Average season total leaves area per plant $=8290.4 \mathrm{~cm}^{2}$, Average total fruits yield per season $=6.0 \mathrm{~kg} /$ plant, Average consumptive water use per season $=18 \mathrm{~L} /$ plant/season, maximum water use efficiency $=333 \mathrm{~g} / \mathrm{L}$, and the cost of produce $1 \mathrm{~kg}$ of pepper fruits was 1.27 L.E. by using the designed HYDROPONIC system.

\section{REFERENCES}

Abou-Hadid et al., (1995). Performance of soilless media on greenhouse production of cucumber, cucumis sativus, in Egypt .Journal vegetable crop production .vol .(1): 93-98.

Ahmed 2003, Studies on producing by using soilless culture techniques. M.Sc. Thesis, Fac.Agric., Ain shams university y, Cairo, Egypt 60-85.

Anonimous 2003, Agricultural statistical book, $2^{\text {nd }}$ edition 2004. The central administration for Agric. Economics, Egypt 50-51.

Bohme 1994, Effects of HYDROPONIC on the development of cucumber growing in ecologically suitable substrates Acta Hort .133-140.

Caldeyro 2003, Improvement of food security and nutrition to children aged 0 to 6, a case study from Ecuador 1, Technical paper: 11-14.

EL Behiary et al., (2001b). Utilization of "A-Shape"system of nutrient film technique (NFT) as a method for production some vegetable crops intensively .pro.5 th IS protect. Cult. Mild Winter Climate. Eds. Fernandez, Martinez \& Castilla Acta Hort.559: 581- 586.

El-Beltage et al., 1992, Interaction between root media and fertilizer for cucumber crops grown in greenhouses.Acta .Hort.323:335 .

Fahem (1989). M.Sc.Design solution membrane meter with agriculture under green house.

Haddad and Boukhris (2003). Growth and quality of tomato plants grown in sand and perlite by the use of geothermal water. Acta Hort. ( ISHS) 609:447-452.

Jensen 1999. Hydroponic Worldwide. Acta Hort .481 : 719-729.

Jensen and Collins 1985, HYDROPONIC vegetable production. Hort Rev., 7: 438- 558 . 
Merle Jensen 1997. Hydroponics. Hortscience., Technical paper: 6: 32.

Ponce, V. M., 1989. Engineering Hydrology, Principles and Practices, Prentice Hall, pages 48-51.

Resh , 1997, Cultivos hydroponics: nuevas técnicas de producción. 4.ed. Madrid: Mundi-Prensa: 378p.

Tuzel et al., (2001). Comparison of open and closed systems on yield, water and nutrient consumption and their environmental impact. Acta, Hort . 554: 221-228.,

Tuzel et al., 1990, Soilless culture for horticulture crop production. Food and agriculture organization of the united nation Roma(FAO) .Lands man's book hop Buckenttil; Bromyard and Hereford, Technical paper : 188.190

\section{المخلص العربي \\ نظام بسيط للزراعة المائية لإنتاج القلقل بالصعيد}

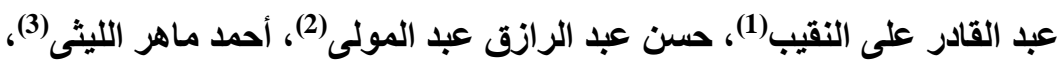

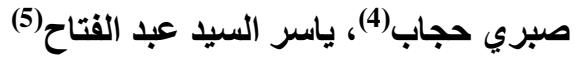

تهدف الدراسة إلى تصميم واختبار نموذج زراعة مائية لإنتاج الفلفل بصعيد مصر

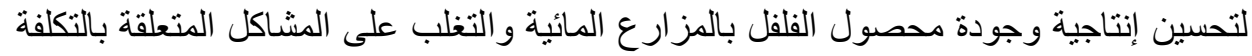

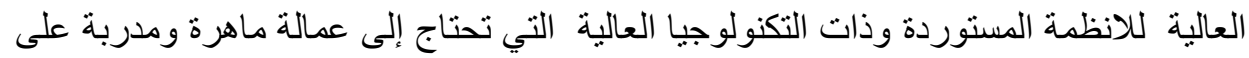

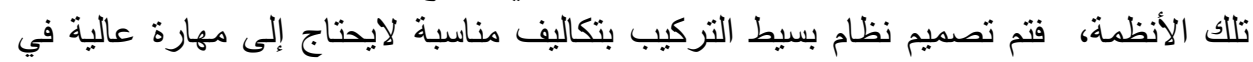

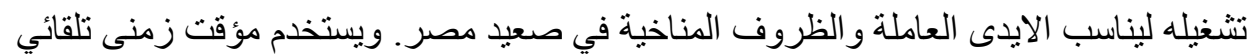

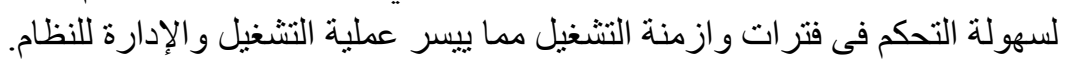

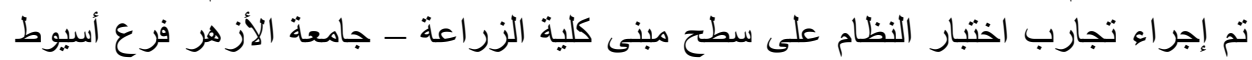

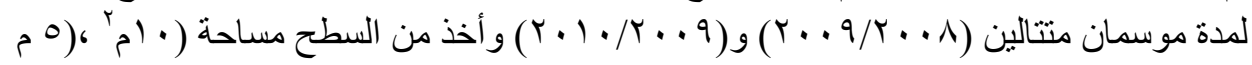

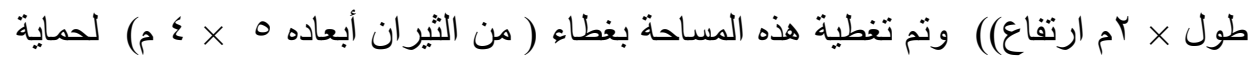

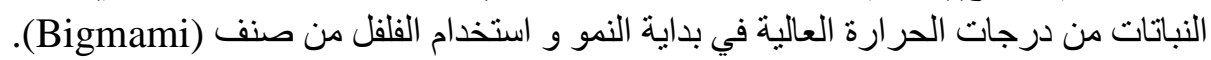

$$
\begin{aligned}
& \text { (1) }
\end{aligned}
$$

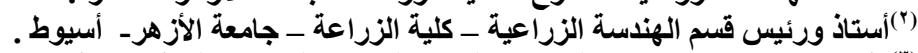

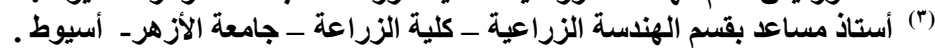

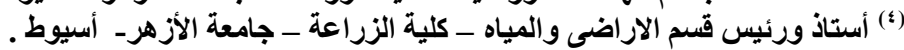

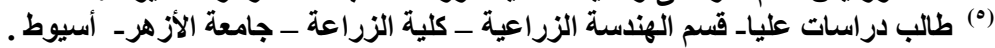




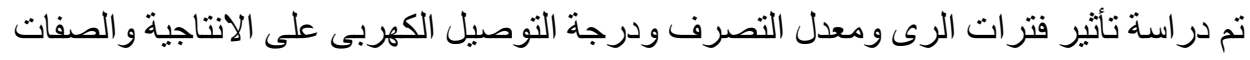

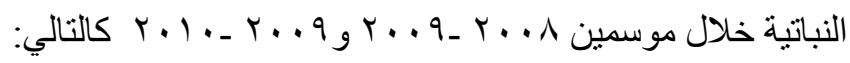

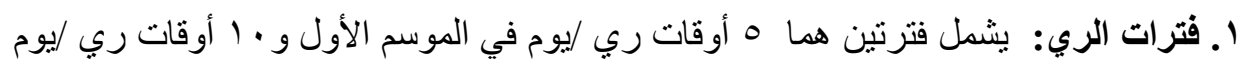
للموسم الثاني كل ريه مدتها 10 أدقيقة.

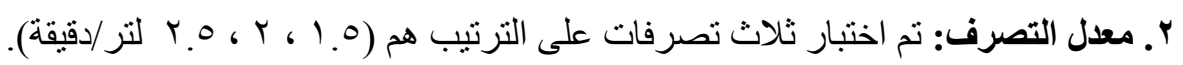
r ـدرجة التوصيل الكهربية : تم اختبار درجتين من الملوحة ( بو ب ملليموز/سم).

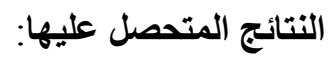
وجد أن أنسب ظروف للحصول على اعلى انتاجية وافضل صفات نباتية كانت كالتالي:

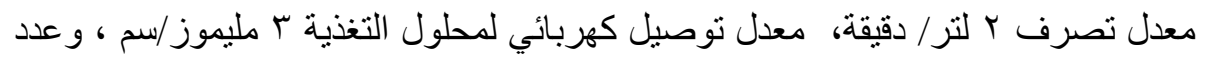

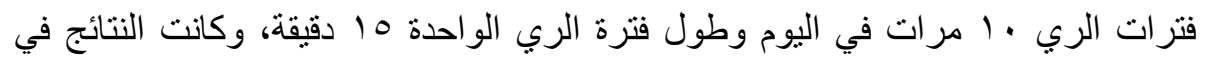

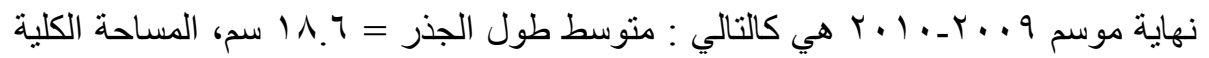

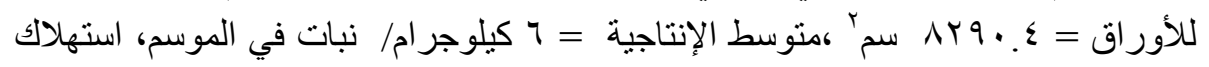

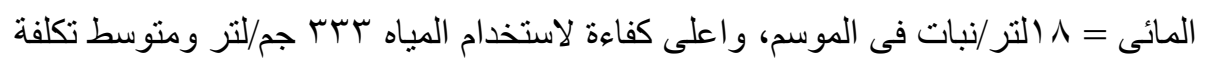

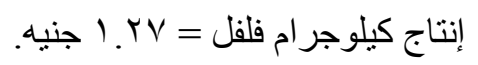

